\section{Market-Oriented Accounting Standard and Analysts' Performance: Evidence from Brazil}

\author{
Talyta Eduardo Oliveira ${ }^{\dagger}$ \\ Universidade Federal do Ceará, Fortaleza, Ceará, Brazil \\ Antonio Carlos Coelho $\Omega$ \\ Universidade Federal do Ceará, Fortaleza, Ceará, Brazil
}

\begin{abstract}
This research investigates if the accounting standard oriented to external users contributes to improve decision-making in the market, represented by analysts' forecast capacity. The hypothesis is that the forecast properties for Brazilian companies' EPS were not impacted by the change in the accounting standard. The data refer to the period 2004-2014; we employed linear multiple regression, estimated through panel data to investigate the accuracy and precision and logistic regression to scrutinize biases. Our findings indicated, with significance, that the analysts' forecasts did not improve, thus, not rejecting the hypothesis. It was highlighted that in the convergence with the new accounting standard, the pessimistic bias was foregrounded, bringing forth analysts' conservatism; the accuracy diminished with the new standard and the precision between periods was not altered. This research lacks depth, considering its low coefficients of determination, and in the sense of determining the causes of such behavior. An inquiry about the utilization of accounting information by analysts was also generated due to the magnitude of the forecast errors detected.
\end{abstract}

Keywords: Market-oriented accounting standard, Market analysts, Forecast Accuracy, Precision and Bias.

\section{INTRODUCTION}

In Brazil, the convergence of accounting standards with the international standard led to changes in the acknowledgment and measurement of economic events, altering the content of the disclosure of the economic-financial situation and the performance of the companies, as of the 2010 financial statements (GRECCO, 2013).

This adopted accounting standard prioritizes the disclosure of the economic essence of transactions, according to their stated purposes; therefore, it is expected that the economic effects will be accurately represented in the financial statements. This imperative of portraying the economic essence of the transaction requires from the accounting professional greater analytical capacity and judgment, when preparing the financial statements (MACEDO; ARAÚJO; BRAGA, 2012).

Similarly, the interpretation and analysis of this information would require, from external users of accounting information, especially market analysts, greater ability to handle the accounting representation
Corresponding author:

† Universidade Federal do Ceará, Fortaleza, Ceará, Brazil.

E-mail: talyta.edu.oli@gmail.com

$\Omega$ Universidade Federal do Ceará, Fortaleza, Ceará, Brazil.

E-mail: accoelho47@gmail.com

Received: $01 / 31 / 2017$.

Revised: 03/15/2017.

Accepted: 05/28/2017.

Published Online: 02/01/2018.

DOI: http://dx.doi.org/10.15728/bbr.2018.15.3.2 
of economic and financial events, as well as knowledge and skills in economics, finance and quantitative methods.

In this context, the research addresses the market analyst as a prominent user of the accounting information, since they use all information publicly available to them, by premise; for this purpose, it is accepted that the financial statements are an important source of information as a basis for cash flows forecasting and recommendations for the buying and selling of securities, in the sense of passing them on, as their product, to investors (LANG; \& LUNDHOLM, 1996; MARTINEZ, 2006, DALMÁCIO et al., 2013; BOFF; PROCIANOY; HOPPEN, 2006).

This assertion is confirmed by Ernstberger, Krotter and Stadler (2008) who showed that in Germany, precision is detected in the estimates produced by analysts, with their accuracy standing out in forecasts based on IFRS accounting standard in relation to projections based on European national accounting standards.

Djatej et al. (2008) - confronting Eastern Europe and Western Europe, and Jiao et al. (2012) - considering analysts' forecasting from the European Union - also converged to such behavior with evidence of more accurate forecasts after adoption of IFRS accounting standard.

On the other hand, Cotter, Tarca and Wee (2012), despite pointing to an increase in the accuracy of analysts' forecasts in the transition period of IFRS adoption in Australia, confirmed that in the post-adoption period of such accounting standard there was a movement to reduce this measure of analysts' performance, the accuracy of forecasts.

In considering their earnings per share forecasts to guide investor decisions, one can expect that the adoption of accounting standard oriented to provide useful information for this task will affect analysts' forecasting ability, in the sense of greater quality in the projection of profits, since there is an expectation of more consistent and relevant informational financial reports.

Although analysts use the accounting information as input to make their forecasts, according to Bryan and Tiras (2007), in a situation of high accounting information asymmetry, they would focus on non-accounting information in order to maintain the explanatory power of their forecasts.

Corroborating Bryan and Tiras (2007), with regard to informational asymmetry, Nogueira et al. (2012) claim that even with the change of accounting standards guided by information relevant to the decision-making of investors, analysts continue to prefer forecasting based on usual methods despite the change in accounting standards.

In Brazil, the strong presence of the government, due to a legal system based on code law and the prevailing orientation of providing information in the form determined by the tax authorities, could weaken accounting institutions from the point of view of the external user and, consequently, generate mistrust in the users of accounting information, especially in the case of specialists.

In light of such evidence, we consider to be appropriate questioning the usefulness of adopting the IFRS accounting standard, if there is no incentive for managers to provide efficient information to analysts and users; we therefore understand that, studies involving effects of convergence to IFRS of low institutional protection, especially in the Brazilian environment, can still add evidence enlightening on the subject.

Market analysts' forecast properties can be tested for the accuracy, precision, and bias of their predictions. The performance of market analysts, measured by these measures, has already been the object of studies by Dalmácio et al. (2013); Martinez (2006); Pessotti (2012); Martinez and Dumer (2014); and Gatsios (2013) in Brazil.

The last three aforementioned research related analysts' forecasts in the Brazilian context with the differences in terms of the current accounting standard, and the findings did not allow identifying if the adoption of IFRS accounting standard contributed to increase 
BBR

15,3

228

analysts' accuracy; on the contrary, Martinez and Dumer (2014) indicate evidence of a reduction in accuracy with the information disclosed in this accounting standard.

Research in other institutional and economic environments developed by Ernstberger, Krotter and Stadler (2008); Djatej et al. (2008); Jiao et al. (2012); and Cotter, Tarca and Wee (2012) are not consensual in their inferences about the effects of accounting information on different standards on improvement in market analysts' forecasts properties.

We then observe that research on the subject in diverse institutional environments attest to divergent inferences about the differentiated use of accounting information by market analysts, given that different accounting standards have not consistently altered the forecasting properties of market analysts.

We therefore have to revisit investigations, as a research question, asking whether analysts' EPS forecasts in the Brazilian market were impacted by convergence to IFRS; we inquired whether the market-oriented accounting standard, to the detriment of the former, focused on control and for the provision of tax information, contributed to increasing the quality of analyzes produced from accounting numbers based on the economic essence of the facts.

Despite Martinez and Dumer (2014) having already signaled a reduction in the accuracy of analysts' forecast post-convergence to IFRS in Brazil, Masoud (2017), who analyzed the impact of the adoption of IFRS on market analysts' forecasting in an emerging country such as Jordan, pointed out that analysts' forecasting errors were reduced by the convergence of their accounting standard to IFRS.

In light of what has been said regarding expectations on the effects of the implementation of a new accounting standard, and considering empirical evidence, both on the national and international scenario, we test the hypothesis that the quality properties of the market analysts' forecasts on EPS in the Brazilian environment were not impacted by the process of changing the accounting standard.

Additionally, we expect when analyzing the evolution of market analysts forecast properties that, as the periods move away from 2004 towards 2014, the frequency of correct consensus forecasts will point to a random and independent path of the current accounting standard, due to the predominance of use of information extraneous to financial reports, observing casual information about various economic-financial moments.

The study is justified by the empirical contribution it can offer to academia on a recent theme that relates effects and evidence concerning the implementation of accounting standards in the perception of external users of accounting information in Brazil, since the evidence in previous research is divergent regarding these effects; it is also motivated to discuss whether the purpose of the accounting standard structure being market-oriented influenced the quality of information usage.

The research breaks new ground as to the format of the test, because in addition to testing the temporal cross-section of changes in analysts' forecast properties as a result of new accounting standard, it considers on the continued effect over the periods under analysis, on the evolution of the behavior of the properties considered, isolating the explicit effect of changing accounting standards.

In proposing such a method, it is understood that there are economic, political and institutional variables that also affect the performance of analysts; thus, the effect of changing the standard can be more consistently specified; similarly, if the behavior of this performance manifests itself as stationary, in returning to the mean, isolating the question of changing the standard, identifying the specific relationship studied more closely.

It is known that accounting information is not the only source of information used by market analysts. Therefore, if these users do not feel secure regarding the accounting information, they will probably use other informational sources for their forecasts, which would be highlighted by the analysis of the evolution of the behavior of properties over time. 


\section{LITERATURE REVIEW}

In the course of its evolution, the role of accounting has been to serve as a control tool for owners and managers of companies, prevailing by exercising the stewardship role, in the view of Murphy, O'connell and Óhógartaigh (2013). Iudícibus (2013) justifies the equity approach in the financial reports due to the fact that the object of the accounting practice in its beginnings was defined peremptorily using the concepts of equity and ownership.

Due to the growth of economic enterprises and the need to raise funds in financial markets, such roles of being accountable to internal users of the entity have become secondary, with an emphasis being placed on conceptual frameworks in force as an object of accounting, and its informational role directed at external users, by means of the financial statements.

In 2004, a conceptual framework was suggested through FASB and IASB that changed the objective of financial reporting of information provider for internal users to suppliers of information for investors (MURPHY; O’CONNELL; ÓHÓGARGATAIGH, 2013).

The financial information of the financial reports is no longer focused solely on equity control so that it is also useful for the decision-making process of investors and capital providers (RAVENSCROFT; WILLIAMS, 2009), although it is clear that control-oriented accounting standard is already a tradition that cannot be totally overlooked to meet the needs of the specific user group (MURPHY; O'CONNELL; ÓHÓRGARTAIGH, 2013).

The change of accounting standard in Brazil - prioritizing the most current concepts generated the opportunity to reflect on the informational increment of financial reports in this sense to efficiently inform the investor for their investment decisions (NOGUEIRA JUNIOR et al., 2012).

The expected informational increment for investors, however, may depend both on the adherence to IFRS and on how the standard is implemented in relation to the previous standards of each country, as according to Ball, Robin and Wu (2003), such convergence occurs differently among countries.

Capital markets in countries with low investor protection policies will experience less benefit from the changing standards than those with a strong investor protection policy, due to the informational increment that the principles-based accounting standard can bring to financial statements.

Ernstberger, Krotter and Stadler (2013) showed that the effects of the change in accounting standards were more positive for German companies that were already voluntarily disclosing in IFRS standards than those that presented financial statements in the German local standard, as an example that the change in the accounting standard depends on local political and cultural factors, as well as the type of user of the information so that it is applied in a way that allows the expected informational increment.

Market analysts are also users of accounting information and can benefit from the adoption of an accounting standard aimed at the external user; for example, one of the changes inserted in the Brazilian accounting scenario, now based on IFRS, compelled companies to disclose cash flow statements (CFS); according to Nogueira Junior et al. (2012), CFS is used by market analysts to assess investment liquidity and may contribute to better forecasts of future EBITDA.

Market analysts are professionals of extreme importance for the capital market, due to the use they make of financial statements, of specific aspects of each economic sector and other business factors (BEIRUTH et al., 2014). Reports prepared by analysts based on accounting information, collaborate with the decision-making of investors (DALMÁCIO et al., 2013).

According to Lima et al. (2009), the way in which analysts reach the forecasts presented in reports depends on the analysis being used, which may be technical or fundamental. Through the technical analysis, values are forecasted using the historical behavior of the
BBR

15,3 
BBR

15,3

stock price, assuming that this behavior will repeat itself, due to the psychological factor among market participants. Forecasts from the fundamentalist perspective consider the strategic analysis of the business, the analysis of the accounting information, the financial analysis and the prospective analysis (PALEPU et al., 2000).

Information contained in analyst reports is expected to be the result of careful examination of financial statements, providing more efficient evidence than investors could obtain by directly analyzing available information (MARTINEZ, 2006).

However, financial reports do not always provide relevant or even sufficient information to analysts; Bryan and Tiras (2007) affirm that in environments where it is possible to identify high informational asymmetry in financial reports the tendency is for analysts to use other sources to subsidize their analyzes, which may reduce the importance and, as a result, the use of accounting information in their tasks.

This situation may occur in countries in which regulatory bodies are neglected in comparison with laws and government requirements. The lack of auditing and severe penalties for those non-conforming with standards can create uncertainty in the disclosed information and thus will likely impact on the choices of such data by analysts, according to these authors.

Thus, analysts would be efficient information intermediaries, regardless of their source, for other users of the market, by means of forecasts or recommendations for the buying and selling of shares.

Analysts' forecasts can be studied from their individual expression or by consensus of the forecasts of the group of analysts. The quality of the forecasts can be evaluated by the error of the forecast, which can be established by the difference in between the observed value and predicted value (DALMÁCIO et al., 2013).

The measurement of error serves as a parameter for analyzing the performance of analysts by measures that represent the accuracy, precision and bias of the forecast in relation to the observed value.

Accuracy will ultimately depend on the precision and bias of analysts' forecasts (MARTINEZ; DUMER, 2014) and can be defined as the measure on the proximity of the value reached in relation to the forecasted value of the object of estimation (DALMÁCIO et al., 2013; MARTINEZ, 2006; MARTINEZ; DUMER, 2014), characterizing itself as the attempt to capture the accuracy of analysts' forecasts (SAITO; VILLALOBOS; BENETTI, 2008).

Accuracy, however, can be seen as the measure of how reproducible the result is (DALMÁCIO et al., 2013), therefore, with it being the measure of variability of estimates published by the group of analysts. On the other hand, bias is considered as the systematic error in the forecasts that causes the average value predicted by the group of analysts to be different from the observed value (MARTINEZ; DUMER, 2014).

Forecasting properties would be related to the quantity and quality of information used by market analysts (MARTINEZ; DUMER, 2014). The greater the number of available sources of information (and the more quality they contain), the more accurate the forecasts would be, enabling forecasts closer to what actually will have occurred.

Although some studies indicate that adoption of the standard based on the international standard has generated positive changes in market analysts' forecasting properties, there is evidence that confronted the pertinence of accounting standard and quality of analysts' forecasts.

Several studies indicated a positive relationship between analysts' performance and change of accounting standard. Ashbaugh and Pincus (2001) investigated whether the change in accounting standard had an impact on the accuracy of analysts around non-US firms and whether this accuracy changed with the adoption of IFRS. 
The research sample was taken from a list of IASC companies, discarding a company group that was not required to file financial reports with the international standard. They found a significant and positive relationship between forecast errors and the practice of accounting standards that are very different from IFRS. They also found that the reduction in analysts' forecast errors was positively associated with companies that started adopting IFRS.

Djatej et al. (2008) investigated the impact of the degree of IFRS implementation on the accuracy and bias of market analysts in companies in 12 Eastern European countries and 17 Western European countries. The results indicated that the accuracy was higher after the implementation of IFRS, with particular emphasis on the forecasts for Eastern Europe which were more accurate than those for Western Europe; the optimistic forecast bias decreased with the implementation of IFRS; for Eastern Europe the performance of analysts stood out with less bias of forecast and lower quantity of optimistic bias.

Ernstberger, Krotter and Stadler (2008) evaluated the influence of the adoption of IFRS on the accuracy of forecasts of financial analysts in Germany. The results suggest that the accuracy of the forecasts was greater for estimates based on IFRS data than for forecasts based on local standards. However, in the year of change of standard the accuracy of the forecasts was lower.

Bae, Tan and Welker (2008) investigated the relationship between countries with different accounting standards and analysts' forecast accuracy. The analyses that were the object of the research were divided into two groups according to the accounting standard adopted in the country of origin of the companies: IFRS and non-IFRS.

It was evidenced that analysts, for the most part, follow companies that disclose statements in IFRS, suggesting, according to the authors, that the adoption of IFRS reduces costs for analysts already familiar with international accounting standards. The accuracy was also higher in forecasts for companies in countries that follow the IFRS.

Tan, Wang and Welker (2011) investigated how the harmonization of accounting standards affected a given group of analysts in 25 countries. They inferred that the mandatory adoption of IFRS attracted foreign analysts to the valuation of companies, which increased the accuracy of the forecasts; and that changing the accounting standard increased the usefulness of the accounting data for financial analysts; however, the forecast accuracy was not affected by the convergence to the new accounting standard.

Jiao et al. (2012) analyzed the effect of the adoption of IFRS on the ability of analysts to translate accounting information into forward-looking information for companies in the European Union, registering an increase in the accuracy of analysts' forecasts.

Petaibanhue, Walker and Lee (2015) examined the comparability benefits of the accuracy of analysts' forecasts after the adoption of IFRS in the European Union; the evidence indicated that IFRS pre-adoption forecasts are less comparable than the pre-adoption forecasts of IFRS.

Masoud (2017) examined the effect of the mandatory adoption of IFRS on the ability of financial analysts to accurately forecast profits in developing countries, Jordan, in the period from 2002 to 2013, showing that over time, forecast errors have been reduced after the adoption of IFRS.

We can observe that in the studies discussed above, the relationship between analysts' performance and change in accounting standards was positive, indicating benefits, although in some studies in the year of change we were not able to identify performance improvement, in some cases there was even a reduction in analysts' performance in the first year of adoption.

The assumptions of such research were constructed based on the idea that the change of standard could bring benefits to analysts' forecast, and this was confirmed; but the topic 
BBR

is questionable since the processes and periods of convergence are different in the study countries.

In another list of research, however, we can observe divergent results. Cotter, Tarca and Wee (2012) found that analysts' forecast for Australian companies improved in the first year of adoption of IFRS; on this occasion, the forecasts did not show significant dispersion, showing that analysts were effective in their forecasting in the transitional period of standards.

However, in the period after the adoption of IFRS, analysts' performance properties decreased, with significant dispersion and declining accuracy, when compared to the year of adoption of the standard. Thus, the results question the timeliness and usefulness of IFRS financial statements if firms did not have strong incentives to provide information that would assist analysts in forecasting.

Pessotti (2012) investigated the impact of convergence to IFRS on the accuracy of Brazilian capital market analysts, in the period from 2000 to 2011, controlling by companies that already published financial statements exclusively in the BR-GAAP standard and by those who were encouraged to disclose their information under US GAAP.

The results indicated that the accuracy was greater when they forecasted for companies that published their financial statements in accordance with IFRS or US GAAP than when they did it based on the Brazilian standard (BR-GAAP). In addition, it was observed that the difference in accuracy was significant for the period of partial and mandatory adoption, emphasizing that accuracy increased in mandatory adoption compared to partial adoption.

Barnive and Myring (2014) examined whether differences between IFRS and US GAAP affected analysts' performance (accuracy and other forecasting measures) and their capacity. The findings indicated forecasting improvement in the year of IFRS adoption, reversed in subsequent periods such a competitive advantage of this accounting standard.

Gatsios (2013) analyzed the impact of convergence on international accounting standards on the predictive quality of accounting information in Brazil. The results indicated that the adoption of the IFRS standard in Brazil has not yet contributed to improving the predictive quality of accounting information, although the forecast bias has decreased. It was noted that analysts' accuracy declined in the period of partial adoption of IFRS and that dispersion increased; in the period of mandatory adoption the evidence found do not allow attributing an increase of accuracy and reduction of dispersion.

Martinez and Dumer (2012) used quarterly EPS forecasts in the years around convergence to IFRS in Brazil (2007 a 2011) investigating accuracy, bias and dispersion in analysts' forecasts. Evidence has shown that accuracy improved with the increase in the number of analysts who accompany the companies and for companies that disclose earnings. Univariate and multivariate tests did not indicate significant changes in the accuracy and bias of forecasts in the same period.

Kim, Kim and Know (2015) analyzed the effects of IFRS on the information environment for financial analysts, specifically on the accuracy of their forecasts in the Korean market, and the findings indicated that forecast accuracy increased for companies listed on KOSIP; as for companies listed on KODASQ, there were indications that it increased the level of earnings management.

We note that there is clearly divergent evidence on the interference of IFRS accounting standard on the quality of market analysts' performance, measured by forecast errors; however, there is no question about analysts' adherence to the preponderant use of accounting information. Changes in accounting practice would only change performance based on accounting information.

The research hypothesis, therefore, is related to the informational increment that the change of standard can provide to market analysts' performance, contingent upon accounting information already affecting their behavior and activity. 
By considering, then, the concept of informational asymmetry involving financial reports and instability of the informational environment dealt with by Bryan and Tiras (2007) and Nogueira et al. (2012), we understand that analysts' forecast will be derived from other market information other than accounting information.

In the Brazilian environment there is no formal evidence on information instability, but there is strong instability in the political, institutional and economic environments, whose information overlaps the less agile information of the accounting by premise.

We can therefore consider that the accounting information does not have a decisive impact on the analysts' forecasts, who would not have paid due attention to the novel purpose of releasing relevant and useful information to the decision of investors and other stakeholders.

We then hypothesized that the quality properties of EPS forecasts by market analysts in the Brazilian environment were not impacted by the process of convergence to IFRS. It is further argued that the time evolution of analysts' performance fails to develop in the direction of improving performance measures.

\section{METHODOLOGY}

Data for the research were collected from the $\mathrm{I} / \mathrm{B} / \mathrm{E} / \mathrm{S}$ database (platform), which provides individual and consensus forecasts of analysts through the Summary History tool; in the Economática database; in SInC software (Corporate Information System), corporate information database available on CVM's DIVEXT and on the BM\&FBovespa website.

On the I/B/E/S platform, we collected quarterly data from consensus market analysts' forecasts related to earnings per share; number of analysts that accompany the companies and the time interval in which the quarterly consensus forecasts were disclosed. From Economática, we collected information related to quarterly earnings per share; market value; profit or loss information and companies issuing ADRs. From SInC, we collected data relating to audit reports. From the BM\&FBovespa we collected information on Corporate Governance.

The companies listed on the BM\&FBovespa and accompanied by analysts, with information on observed EPS and projected EPS, composed the sample of quarterly consensus forecast (performed by more than one analyst) of the EPS for each year from 2004 to 2014; considering companies with complete quarterly data for all variables surveyed, we reached a total of 188 companies.

From 5,090 observations of original quarterly forecasts we removed those with data absence and outlier condition identified by bloxplot based on disparate values for the measure of accuracy; as we used consensus analyst forecasting data, we also discarded observations on companies followed by only one analyst in that quarter, with 4,405 remaining valid observations, which implies an unbalanced sample, as detailed in table 1.

The number of forecasts increases over time with the last quarter appearing with higher numbers. We highlight that variations in the number of companies analyzed are observed in the period of implementation of the new standard: 2007 for 2008 and 2010 for 2011.

In the period from 2004 to 2006, in addition to a small number of companies, compared to other periods, it is noted that many companies were followed by only one analyst. The discarded data presented in Table 1, despite being consensual and having all the research requirements, fit the condition of outliers.

We used three models to test the hypothesis raised; the first one observed whether the accuracy of the forecasts grew with the use of information from the new accounting standard.

The second examined the accuracy of forecasts, comparing the dispersion of EPS forecasts from the group of analysts before and after the change in the accounting standard. 
Table 1. Consensus forecasts sampled

\begin{tabular}{|c|c|c|c|c|c|c|}
\hline Year & $1^{\text {st }}$ quarter & $2^{\text {nd }}$ quarter & $3^{\text {rd }}$ quarter & $4^{\text {th }}$ quarter & Total & Discarded Data \\
\hline 2004 & 32 & 33 & 36 & 36 & 137 & 8 \\
\hline 2005 & 39 & 40 & 40 & 45 & 164 & 4 \\
\hline 2006 & 45 & 46 & 48 & 49 & 188 & 4 \\
\hline 2007 & 65 & 65 & 69 & 77 & 276 & 3 \\
\hline 2008 & 98 & 100 & 105 & 107 & 410 & 3 \\
\hline 2009 & 110 & 103 & 101 & 110 & 424 & 6 \\
\hline 2010 & 107 & 108 & 117 & 123 & 455 & 6 \\
\hline 2011 & 131 & 132 & 138 & 147 & 548 & 3 \\
\hline 2012 & 155 & 146 & 147 & 152 & 600 & 11 \\
\hline 2013 & 153 & 153 & 150 & 155 & 611 & 4 \\
\hline 2014 & 141 & 156 & 151 & 144 & 592 & 2 \\
\hline Total & 1076 & 1082 & 1102 & 1145 & 4405 & 54 \\
\hline
\end{tabular}

The third assessed the likelihood of bias contained in the EPS forecasts being mitigated under the new accounting standard.

The models were built based on Dalmácio et al. (2013); Pessotti (2012); Gatsios (2013) and Martinez and Dumer (2014) and were processed on two perspectives, one which is to examine the temporal evolution of these measures and to focus on the differences between them when the periods before and after IFRS convergence are segmented.

These two approaches seek, respectively, to ratify the temporal adherence of analysts' performance without the explicit interference of the focused accounting event, and to test the hypothesis of change in analysts' performance expressed by the temporal cross-section between the events before and after the new accounting standard.

We applied model (1) for the two approaches distinguished by the last variables, segregating the two situations:

$$
\begin{gathered}
A P_{i, t}=\beta_{0}+\beta_{1} C O V_{i, t}+\beta_{2} L A G_{i, t}+\beta_{3} S I Z_{i, t}+\beta_{4} S R_{i, t}+\beta_{5} \text { BigFour }_{i, t}+\beta_{6} C G_{i, t} \\
+\beta_{7} A D R_{i, t}+\beta_{8} N A S+\beta_{9} Y E A R+\varepsilon_{i}
\end{gathered}
$$

Where:

$\mathrm{AP}_{\mathrm{i}, \mathrm{t}}=$ Analysts' Performance, measured by: Accuracy, Precision and Bias, the measures of quality of analysts' consensus forecast (average) for each i company in period t;

$\mathrm{COV}_{\mathrm{i}, \mathrm{t}}=$ Coverage, measured by the number of analysts who follow company $\mathrm{i}$ in each period t;

$\mathrm{DEF}_{\mathrm{i}, \mathrm{t}}=$ Time Lag between the time of forecasting and the observed EPS period, measured by the $\log$ of the number of quarters for each company $\mathrm{i}$, in each quarter $\mathrm{t}$;

$\mathrm{SIZ}_{\mathrm{i}, \mathrm{t}}=\log$ do valor de mercado da empresa $\mathrm{i}$, no período $\mathrm{t}$;

$\mathrm{SR}_{\mathrm{i}, \mathrm{t}}=$ Dummy for the EPS situation of company $\mathrm{i}$ in period $\mathrm{t} ; 1$ for positive result; 0 otherwise;

BigFour $_{\mathrm{i}, \mathrm{t}}=$ Control for the audit firm of company $\mathrm{i}$ in period $\mathrm{t} ; 1$ for audited by Big Four; 0 otherwise;

$\mathrm{CG}_{\mathrm{i}, \mathrm{t}}=$ Control for the listing at levels of corporate governance of company $\mathrm{i}$ in period $\mathrm{t}$; 1 for special listings; 0 otherwise;

$\mathrm{ADR}_{\mathrm{i}, \mathrm{t}}=$ Control for ADR positioning of company $\mathrm{i}$ in period $\mathrm{t} ; 1$ for issuing companies and 0 otherwise;

NAS = Dummy indicating the change in the accounting standard; 1 for the IFRS period and 0 otherwise; 
YEAR $=$ Control for the annual evolution of analysts' performance, by means of dummies for each sample period;

$\varepsilon_{\mathrm{i}}=$ Error term model for company i.

The accuracy of the forecasts was measured by representing analysts' consensus for each unique period (DALMÁCIO et al., 2013; MARTINEZ, 2006; PESSOTTI, 2012; MARTINEZ; DUMER, 2014), in accordance with equation (2):

$$
\text { Accuracy }=(-1)\left|\frac{E P S_{\text {obs }}-E P S_{\text {pred }}}{E P S_{\text {obs }}}\right|
$$

Where:

$\mathrm{EPS}_{\mathrm{obs}}=$ Observed earnings per share;

EPS $_{\text {pred }}^{\text {obs }}=$ Consensus forecast earnings per share.

Measurement by the forecasting error module considers errors regardless of whether they are positive or negative, so that accuracy is given by the proximity of the zero measure. The inversion of the module sign facilitates the interpretation of this measure (DALMÁCIO et al., 2013).

The precision of the forecasts was measured by the dispersion of individual analysts' forecast in relation to the consensus forecast (MARTINEZ, 2006; COTTER; TARCA; WEE, 2012), in accordance with equation (3):

$$
\text { Precision }=\sqrt{\sum_{i=1}^{n} \frac{E P S_{\text {ind }}-\overline{E S P} \text { pred }}{n-1}}
$$

Where:

$\mathrm{EPS}_{\text {ind }}=$ Earnings per share estimated by individual analysts;

$\mathrm{EPS}_{\text {pred }}=$ Average of consensus forecasted earnings per share;

$\mathrm{n}=$ number of forecasts.

The lower the forecast dispersion the greater its precision, i.e., the more consensual the forecasts will be in relation to the interpretation of available information. With greater dispersion, less forecasting accuracy is indicated, and may be a sign of inconsistency of divergent methods or databases used for forecasting.

The bias was measured by the formula that calculates the forecast error (MARTINEZ; DUMER, 2014; DALMÁCIO et al., 2013; MARTINEZ, 2006), in accordance with equation (4):

$$
\text { Bias }=\frac{E P S_{\text {obs }}-E P S_{\text {pred }}}{\left|E P S_{\text {obs }}\right|}
$$

Where:

$\mathrm{EPS}_{\mathrm{obs}}=$ Observed earnings per share;

$\mathrm{EPS}_{\text {pred }}=$ Consensus forecast earnings per share.

The use of modulus in the denominator prevents that occurrence of losses from obstructing the direction of the forecast error. The bias will have been optimistic when the difference between the observed EPS and the predicted EPS is negative. With pessimistic bias, most certainly, analysts will have estimated lower profits than the observed (MARTINEZ; DUMER, 2014; GATSIOS, 2013). 
BBR

We tested the expected transformation in the informational quality due to IFRS by the behavior of the $\beta_{8}$ coefficient relative to the temporal cross-section by the validity of the accounting standard; as for the evaluation of the evolution of the quality of analysts' performance was estimated by the $\beta_{9}$ coefficient in relation to all the evaluated periods of the research.

The technique that analyzes the evolution of forecasting properties over time was based on Hauser (2013), and in an analogous way, it intends to compare progress in the quality of analysts' forecasts throughout the learning derived from accounting information or competing information, all of which are explicitly addressed to their task.

The introduction of variables related to temporal evolution both increased the explanatory power of the models and incremented the significance of explanatory variables listed as performance drivers.

In addition, we checked if there was a tendency already of more efficient analysts' forecasts during the quarters that preceded the period of adoption of the new standard and also whether the learning effect was registered after the consummation of the implemented standard.

It would be expected that from 2004 to 2008 such coefficients would have remained constant, allowing us to infer that the characteristics of the forecasts did not change in the period previous to the changes of the accounting standard. The positive increase in the coefficients is expected from 2009, signaling the relevance of the change of accounting standard in analysts' performance.

Research such as by Martinez (2006), Dalmácio et al. (2013), Pessotti (2012) and Gatsios (2013) listed variables that are assumed to determine the performance of analysts' forecasts. Selected attributes based on the existing literature to regress performance measures of sampled analysts showed low coefficients of determination $\left(\mathrm{R}^{2}\right)$, although significant, emphasizing the existence of omitted variables in an attempt to explain analysts' performance.

However, the power of determination of the models is heterogeneous in both national and international literature; the studies by Martinez and Dumer (2014) and by Jiao et al. (2012) also had low explanatory power for accuracy; Gatsios (2013), on the other hand, they found explanatory power between $11 \%$ and $17 \%$, adding measures of ROE and Risk to the model, in addition to accuracy being measured differently in relation to this research.

We noticed that the explanatory power of the accuracy model increased when information on bias and dispersion of forecasts were included; Dalmácio et al. (2013) presented explanatory power of the model above $26 \%$, and Pessotti (2012), above $70 \%$, with bias and precision serving as control. Dalmácio et al. (2013) also used price-to-book, sector and volatility of the results as drivers of forecasts.

In the international literature, the explanatory power of the accuracy models is also heterogeneous; Byard et al. (2011) presented explanatory power of $44 \%$ and Jiao et al. (2012) showed low explanatory power, between $0.05 \%$ and $11 \%$. Reduced explanatory power for the relationship between accuracy and change of accounting standard was also found by Jiao et al. (2012).

Even with such evidence and without seeking to exhaust the list of determining factors, we select variables representing attributes capable of increasing the determination power of models that have the purpose of the research, by premise, which are:

- Coverage (COV): the greater the number of analysts who follow the company, greater than the expected proximity of the predicted value to the value observed in the attributes under analysis (LYS; SOON, 1995; ABSHBAUGH; PINCUS, 2001; MARTINEZ, 2006; YU, 2005; ERNSTBERGER; KROTTER; STADLER, 2008; DALMÁCIO et al., 2013; PESSOTTI, 2012; GATSIOS, 2013; HOUQE; EASTON; ZIL, 2014); 
- Time Lag (LAG): the closer the date of the observation forecast, the greater the accuracy and precision and the lower the expected bias (RICHARDSON et al., 1999; FRANCO, 2002; MARTINEZ, 2006; DALMÁCIO et al., 2013; PESSOTTI, 2012; BAE; TAN; WELKER, 2008; ERNSTBERGER; KROTTER; STADLER, 2008);

- Size (SIZ): the larger the company, the higher the expected quality of the disclosed informational content, higher accuracy and lower the dispersion of analysts' forecasts (LANG; LUNDHOLM, 1996; DALMÁCIO et al., 2013; BAE, TAN; WELKER, 2008; PESSOTTI, 2012; GATSIOS, 2013; HOUQE; EASTON; ZIJL, 2014; ERNSTBERGER; KROTTER; STADLER, 2008);

- SR: reporting positive results lead to more appropriate forecasts;

- Big Four: forecasts for Big Four audited accommodate more accurate forecasting properties (BEHN, CHOI; KANG, 2008; DALMÁCIO et al., 2013; GATSIOS, 2013);

- CG: companies in governance listings would be better evaluated (DALMÁCIO et al., 2013; PESSOTTI, 2012; GATSIOS, 2013; ERNSTBERGER; KROTTER; STADLER, 2008; AHMAD-ZALUKI; WAN-HUSSIN, 2010);

- ADR: statements contribute to forecasting quality (TAN; WANG; WELKER, 2011; PESSOTTI, 2012; GATSIOS, 2013).

We performed a descriptive statistical analysis (FÁVERO et al., 2009) in order to know the temporal behavior of the attributes, examining the occurrence of changes in the accounting standard, using parametric and nonparametric tests for equality of mean and the ANOVA technique comparing the accuracy and precision of the analysts' forecasts. We also tested the frequency of the type of bias in the periods segmented by the introduction of the new accounting standard by means of the $\chi^{2}$ test.

We performed the multivariate analysis in order to test the influence of determinants on analysts' performance, considering both the attributes of interest, namely, the change of accounting standards and the evolution of analysts' performance, as the influence of other variables, by means of Ordinary Least Squares (OLS), with estimation of coefficients by panel data, for the models that investigated accuracy and precision and through logistic regression to estimate coefficients relative to the model that addresses the forecast bias.

We tested the model that analyzes the temporal evolution of the accuracy by the BreuschPagan LM test (38.84***); Hausman test (15.09) and the Chow F statistic (2.29***), which indicated random effects estimation. The accuracy model that examines the influence of the new accounting standard was estimated by random effects, as indicated by the tests of Breusch-Pagan LM (40.88***); Hausman (6.61) and Chow F (2.3***).

We tested the model that analyzes the temporal evolution for precision by Breusch-Pagan LM test (3269.55***); Hausman (19.93***) and Chow F (5***), results indicating random effects estimation. As for the precision model on impact of the new accounting standard, the indication of the tests is for the estimation by fixed effects to occur, as indicated by Breusch-Pagan LM test (3234.83***); Hausman (16.60**) and Chow F (15.67***).

To mitigate issues related to heteroscedasticity in accuracy and precision processing, we used White's robust adjustment. As for the logistic regression processing, we verified the absence of multicollinearity, whose results are not reported.

\section{RESULTS}

Table 2 shows analysts' performance, in a univariate manner; in panel A, we can observe that the accuracy in EPS predictions is significantly different between the studied periods, with the differentiation being highlighted after convergence to IFRS; in each of the periods, however, it can be seen that the accuracy was similar in behavior over the time interval of the research; there is also a high variability between the indicators of accuracy over the period under analysis. 
BBR

15,3

Table 2. Analyst Performance - Descriptive Statistics

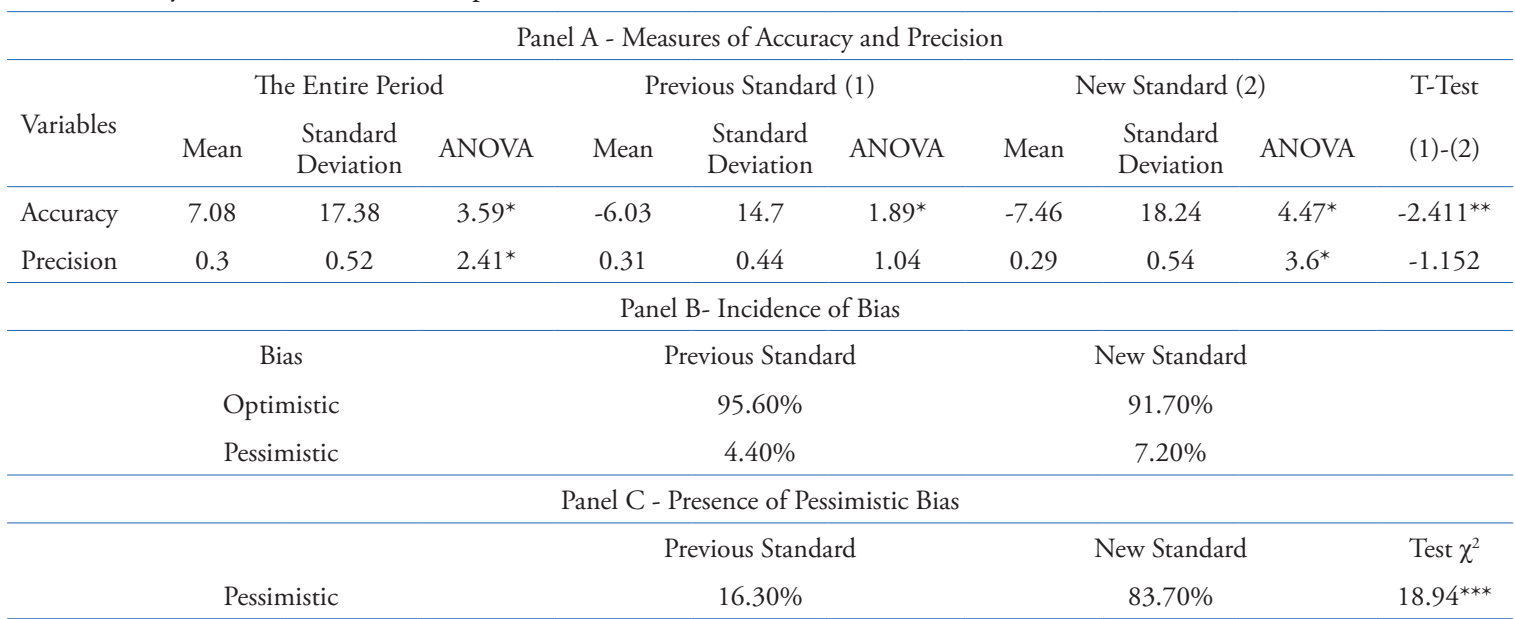

Note: Level of significance: ${ }^{*} 10 \%$; ${ }^{* *} 5 \%$; ${ }^{* * *} 1 \%$.

We identified low accuracy in the projected EPS, with divergences around 7 times in relation to the observed EPS, on average, which corroborates the findings of Dalmácio et al. (2013), Pessotti (2012) and Martinez and Dumer (2014), already pointing to a strong separation between the accounting outcomes and those projected by analysts, suggesting biased forecast in relation to accounting information.

Analysts' forecasting errors grow in the most recent period, identifying decreased accuracy of forecasts in the new accounting standard (from -6.03 to -7.46 on average) indicating, significantly, less accurate forecasts; although this result cannot be attributed to the quality of the accounting information, we emphasize that this behavior is contrary to what is expected by logic, that the IFRS is being directed to the investing user.

In panel $A$ we also notice that the precision of forecasts by the group of analysts is homogeneous between the periods separated by the accounting change; however, when examining the relationship within each period, we note that the remotest period did not show differences between the years, with its precision becoming differentiated in the new period; such assertions are statistically supported.

This measure behaves with important variability over the periods, with coefficient of variation oscillating around 1.50, which corroborates previous studies by Gatsios (2013), Jiao et al. (2011) and Cotter, Tarca and Wee (2012) and demonstrates differentiated methods among analysts.

When comparing the precision of analysts' consensus in the periods before and after IFRS, there is a homogeneous behavior in the group of analysts, regardless of the accounting standard in force.

By panel B we understand that the bias in EPS forecasts is predominantly optimistic (corresponds to more than $90 \%$ of the sample) for the analyzed period with a slight tendency for pessimistic evaluations in the new accounting standard.

Given the predominance of optimistic bias throughout the analysis period, we examined in panel $\mathrm{C}$ the specific behavior of the pessimistic bias, considered as the most effective in terms of investor orientation. Their frequency was statistically different and greater in the period of the new accounting standard, indicating that analysts had adopted more realistic forecasts in this reality.

In table 3 we examine the behavior of decisive attributes for analysts' performance; in Panel A, it is noted that the number of analysts covering each company has increased significantly, evidencing greater coverage of companies after change of accounting standard. The lag between the time of forecasting and the occurrence of the observed does not show differences between the behavior in the previous standard and in the new standard. 
Table 3. Determinants of Analysts' Performance

\begin{tabular}{|c|c|c|c|c|c|}
\hline \multicolumn{6}{|c|}{ Panel A - Quantitative variables } \\
\hline \multirow{2}{*}{ Variables } & \multicolumn{2}{|c|}{ Previous Standard (1) } & \multicolumn{2}{|c|}{ New Standard (2) } & \multirow{2}{*}{$\begin{array}{l}\text { T-Test } \\
\text { (1)-(2) }\end{array}$} \\
\hline & Mean & Standard Deviation & Mean & Standard Deviation & \\
\hline $\mathrm{COV}$ & 0.67 & 0.25 & 0.8 & 0.27 & $14.25^{* * *}$ \\
\hline LAG & 2.48 & 0.1 & 2.48 & 0.09 & 0.91 \\
\hline SIZ & 6.73 & 0.64 & 6.67 & 0.63 & $-2.65^{* * *}$ \\
\hline \multicolumn{6}{|c|}{ Panel B - Binary variables - Test $\chi^{2}$} \\
\hline Variables & \multicolumn{2}{|c|}{ Previous Standard (1) } & \multicolumn{2}{|c|}{ New Standard (2) } & Test $\chi^{2}$ \\
\hline \multirow{2}{*}{ SR } & Earnings & Loss & Earnings & Loss & (1) - (2) \\
\hline & $90 \%$ & $10 \%$ & $84 \%$ & $16 \%$ & $25.81^{* * *}$ \\
\hline \multirow{2}{*}{ Big Four } & Big Four & All Others & Big Four & All Others & \multirow{2}{*}{$45.05^{* * *}$} \\
\hline & $88.90 \%$ & $11.10 \%$ & $94.70 \%$ & $5.30 \%$ & \\
\hline \multirow{2}{*}{ CG } & New Market & Traditional & New Market & Traditional & \multirow{2}{*}{$100.06^{* * *}$} \\
\hline & $47.80 \%$ & $52.20 \%$ & $64.50 \%$ & $35.50 \%$ & \\
\hline \multirow{2}{*}{$\mathrm{ADR}$} & Yes & No & Yes & No & \multirow{2}{*}{$73.62^{* * *}$} \\
\hline & $44.90 \%$ & $55.10 \%$ & $34.00 \%$ & $66 \%$ & \\
\hline
\end{tabular}

Note: Binary variables represented by percentages; Level of significance: ${ }^{*} 10 \%$; ${ }^{* *} 5 \%$ and ${ }^{* * *} 1 \%$.

The size of companies followed by analysts showed significant difference between the periods observed, with lower market value in the period of validity of the new accounting standard.

According to panel B, we noticed that the listed factors presented relevant and significant changes between the periods studied with less frequency of companies with a profit; greater frequency of companies audited by Big Four; higher frequency of companies in the New Market segment and lower frequency of companies with ADR issuance.

We then examine the marginal impact of the conditioning factors of analysts' performance on EPS forecast by using the multivariate method (accuracy, precision and bias), in the information presented in table 4 .

The attributes related to analysts (coverage and lag) and earnings reporting are the only ones that contribute positively to greater accuracy in the forecasts.

As for the precision of the group of analysts, it is explained by coverage, size, profit and ADR, with differentiated senses; higher coverage, lower accuracy; larger companies, greater precision, higher accuracy with reported profit and lower convergence of forecasts in face of ADR issuance.

Given that the accuracy of analysts' forecasts may be affected by the diversity of information sources and multiple valuation methods and style, the heterogeneous behavior identified is natural.

The pessimistic bias is stimulated due to the greater distance between the forecast and the occurrence of the fact and in companies with ADR issuance; as for coverage extension, loss reporting, audits of lesser expression and size stimulate forecasts with optimism.

Attributes indicative of the capacity to capture information seem to be associated with the existence of optimistic biases, perhaps due to lower access to more reliable sources and by referring to firms less exposed to markets and scrutiny.

One can ponder, in evaluating the temporal evolution of aggregation between drivers and analysts' performance that economic, political, and social events will have affected the quality of the forecasts, since there is a significant change in the coefficients linked to the years, and it cannot be explicitly linked to accounting changes in progress.

As suggested in the hypothesis formulation, such movements are erratic in relation to the accounting practice, which did not change over the whole period, and it may be induced, 
BBR

15,3

240

Table 4. Accounting Standard and Analyst Performance

\begin{tabular}{|c|c|c|c|c|c|c|}
\hline \multirow{2}{*}{$\begin{array}{l}\text { Determinant } \\
\text { Factors }\end{array}$} & \multicolumn{3}{|c|}{ Temporal Evolution } & \multicolumn{3}{|c|}{ Temporal cross-section } \\
\hline & Accuracy & Precision & Bias & Accuracy & Precision & Bias \\
\hline $\mathrm{COV}$ & 3.30 & 0.10 & $-1.21^{* * *}$ & 3.80 & 0.06 & $-1.22^{* * *}$ \\
\hline LAG & $6.10^{*}$ & -0.11 & $1.63^{* * *}$ & $8.60^{* * *}$ & -0.17 & 0.67 \\
\hline SIZ & 1.13 & $-0.07^{* * *}$ & $-0.46^{* * *}$ & 1.21 & -0.07 & $-0.45^{* * *}$ \\
\hline SR & $3.70^{* *}$ & -0.03 & $-1.04^{* * *}$ & $3.80^{* * *}$ & -0.02 & $-1.10^{* * *}$ \\
\hline Big Four & -1.40 & 0.00 & $-0.69^{* * *}$ & -0.9 & -0.04 & $-0.65^{* * *}$ \\
\hline CG & 0.10 & -0.04 & -0.13 & 0.10 & 0.01 & -0.14 \\
\hline ADR & 0.52 & $0.10^{*}$ & $0.74^{* * *}$ & 0.48 & 0.05 & $0.77^{* * *}$ \\
\hline NAS & & & & $-1.24^{* *}$ & 0.02 & $0.84^{* * *}$ \\
\hline 2005 & -1.47 & 0.046 & $-1.00^{* *}$ & & & \\
\hline 2006 & $-3.59^{* *}$ & 0.03 & $-1.13^{* *}$ & & & \\
\hline 2007 & -1.43 & 0.06 & -0.33 & & & \\
\hline 2008 & $-2.00^{*}$ & 0.09 & $-1.30^{* * *}$ & & & \\
\hline 2009 & $-4.38^{* * *}$ & $0.17^{* * *}$ & -0.07 & & & \\
\hline 2010 & -1.52 & 0.06 & -0.41 & & & \\
\hline 2011 & $-2.03^{*}$ & 0.03 & $-0.67^{*}$ & & & \\
\hline 2012 & $-2.58^{* *}$ & 0.03 & 0.18 & & & \\
\hline 2013 & $-3.91^{* * *}$ & 0.07 & 0.13 & & & \\
\hline 2014 & $-3.64^{* * *}$ & 0.04 & $0.58^{*}$ & & & \\
\hline Intercept & $-32.30^{* * *}$ & $0.93^{* * *}$ & -1.39 & $-41.90^{* * *}$ & $1.16^{* * *}$ & 0.16 \\
\hline Forecast & Random Effects & Random Effects & LOGIT & Random Effects & Fixed Effects & LOGIT \\
\hline Fitting statistics & $94.39^{* * *}$ & $94.39^{* * *}$ & $266.79^{* * *}$ & $47.49^{* * *}$ & $3.46^{* * *}$ & $223.40^{* * *}$ \\
\hline $\mathrm{R}^{2}$ adjusted & $2.20 \%$ & $4.26 \%$ & $11.65 \%$ & $1.83 \%$ & $1.11 \%$ & $9.76 \%$ \\
\hline
\end{tabular}

for a more explicit examination, that the accounting numbers contain little informational content, in an asymmetric environment.

The most jeopardized measure as an effect of time is accuracy; in the most recent years forecasts are less accurate, whether due to variability in the economic environment, either because of the difficulty in interpreting accounting aggregates after convergence.

After the period of mandatory adoption of the new Brazilian accounting standard, the accuracy of analysts' forecasts is reduced each year. When analyzing the period from 2005 to 2014, we noticed that the periods in the previous standard were not significant, indicating the possibility of a strong informational asymmetry between the accounting and the product of analysts.

In this regard, the moment of change of the accounting standard corroborates the behavior indicating with significant reduction in the accuracy of the analysts for EPS forecast, probably linked in other evidence and events not captured by accounting information.

These findings corroborate Gatsios (2013), who suggests an accuracy found in 2009 lower than that identified in 2006; the time evolution leads to the conclusion that even the full and mandatory implementation of IFRS contributed marginally to rejecting superior performance due to convergence.

On the other hand, the temporal evolution of precision is presented with coefficients of smaller magnitude and always positive, when significant, suggesting that analysts' work tended to be less precise over the period studied. We highlight that only the year of 2009 presented significance, indicating that the standard does not influence the variations of profits predicted by analysts. 
It should be noted that the year that presented significance for accuracy is within the period after convergence to IFRS, however, we cannot infer that the language of the reports have led to a lesser consensus of understanding by analysts.

This low precision among analysts can be attributed to the process of adaptation to the new accounting standard, since the forecasts were performed still in the period before the change. The year of 2009 presented less analysts' consensus, in the period of partial adoption of IFRS, corroborating Gatsios (2013), who found greater dispersion in the same period.

This trend is not identified by the time-lag coefficient, and there is no influence of convergence on the accuracy of forecasts. The findings, in this respect, corroborate Martinez and Dumer (2014), which show estimates with great dispersion for the whole period analyzed, not attributing the analysts' precision to the new accounting standard.

As with the accuracy, precision did not show evidence that the change in accounting standard allowed marginal increase in analysts' performance, with regard to greater accuracy and greater precision; such an inference diverges from Jiao et al. (2012) in terms of precision.

In Brazil, evidence of low performance in accuracy and precision was documented, regardless of the accounting standard by Martinez (2007), with a reduction in the performance of accuracy and precision in the studied period.

As for the evolution of the temporal influence on forecast bias we cannot deduce a defined direction from the analysis of the coefficients, leading to the belief that circumstantial factors may affect such analysts' behavior much more than analytical factors or specific attributes of any order, and we cannot define a trend for the set of analyzed years as to the probability of an optimistic or pessimistic EPS statement.

In the model that considers the temporal cross-section, one can see that the adoption of a new accounting standard influenced the bias of analysts' forecasts (significance of the coefficient representing convergence to IFRS); considering its positive sign, it is inferred that the bias began to appear mostly pessimistic in analysts' forecast.

Thus, it is possible to attribute the conservative behavior of analysts to IFRS, perhaps for more information options supporting more realistic forecasts; however, due to the low coefficient of determination of the model, indicating the existence of omitted variables, it would be unreasonable to assign the preponderance of pessimistic bias in the prediction of analysts only the effects of change in accounting standards; Martinez and Dumer (2014) found no significance between the bias and the change of Brazilian accounting standard, despite using a methodology different from the one applied.

\section{CONCLUSION}

We investigated the performance of market analysts in forecasting EPS of Brazilian firms, in view of the drivers of their activity, focusing on the convergence of the Brazilian accounting standard with the IFRS principles, as a catalyst for the increase of the properties of the actual forecast.

For this purpose, we took advantage of the conceptual change of the Brazilian accounting standard, which began to emphasize investors-oriented information to facilitate their decision-making process to supply resources for firms.

The studies by Ashbaugh and Pincus (2001), Djatej et al. (2008), Ernstberger, Krotter and Stadler (2008), Bae, Tan and Welker (2008), Tan, Wang and Welker (2011), Jiao et al. (2012), Petaibanhue, Walker and Lee (2015), Masoud (2017) inferred positive relationship between change in accounting standard and analysts' performance. As for the research by Pessotti (2012), Barnive and Myring (2014), Gatsios (2013), Martinez and Dumer (2012) 
BBR

and Kim, Kim and Know (2015) indicated a negative or non-significant relationship for such relationship.

In light of these results, we noticed that there is no consensus on the effect of a marketoriented accounting standard on analysts' forecasting properties, leading to replication, widening the scope and methods in the Brazilian environment on analyst performance.

The contributions of the research can be summarized in the sense that the hypothesis of independence from the quality of market analysts' forecasts due to the targeting of the accounting information for investors has not been rejected. The set of quality measures studied, however, continue to point out divergent indications about such inference, with a conclusion on the subject not being reached.

The reasons for such conclusions can be explained from the low coefficients of the models, which indicate an overload of unobservable variables in the performance evaluation of market analysts.

Given the behavioral aspects and even the innumerable sources of information and the interests involved in forecasts disclosure, we can intuit that econometric models fail to capture the complex structure underlying the decision to report estimates.

Such difficulty can be exemplified by the average error in the measurement of accuracy, since this topic imports differences of the order of $700 \%$, showing a fundamental discrepancy, for the whole period, between the observed accounting numbers and the consensus forecasts published by analysts.

In addition, the dispersion around this difference (Observed EPS - Forecasted EPS) among analysts did not present itself with such scope; the precision in the forecast of the group of analysts appeared to be convergent, i.e., they all present the same tendency to the aforementioned error.

This means that we are faced with the alternative that financial reports are not considered for analysts' forecasts, which would disqualify accounting information as having valuerelevance in their view; or that the forecasts are directed to the concept of stock returns, which would imply conceptual error derived from the little use of accounting for this purpose.

It is worth mentioning that the role of financial reports would continue to be seen as a source of specific facts that provide information on possible future gains or losses and not as a structure that leads to the final value of the company's performance. In this case, one can also expect a longer learning period for both those producing and using financial reports in the spirit of IFRS principles.

The findings about the moment when the new accounting standard begins to be practiced do not allow us attributing the worst performance shown by analysts in specific to the accounting model as there are other factors may have contributed for this purpose. It should be highlighted, above all, the environment of high informational asymmetry preponderant in the Brazilian reality.

The expected benefits of adopting the new accounting standard information directed to the information of users have not yet significantly impacted the behavior of market analysts; under the new accounting standard, on the other hand, we noticed that analysts were more cautious in the disclosure of forecasted EPS, behavior reflected in more pessimistic biases, in the second period, which can be thought of as a function of the economic reality of the period.

The justification for the results indicating that there was no improvement of forecasting properties over time in Brazil can be attributed to the fact that despite the changes in accounting standards, which privilege the economic essence of the transaction, analysts did not change the form and database used to carry out forecasts, as already expressed by Nogueira Junior et al. (2012, p.50), who say that even in the context of changing accounting standards, analysts "prefer to carry out their economic value forecasts using valuation 
methods based on net income, adjusted for the transactions that impact the cash flow of a company".

The pessimistic behavior of analysts can be justified by the different forms of interpretation provided by the new accounting standard that may have left analysts more conservative. However, the decrease in the performance of the accuracy and precision of analysts' forecasts and the increase in the pessimistic bias cannot be attributed solely to the change in the accounting standard, because studies prior to the change in accounting standards already indicated these characteristics - Martinez (2007) - as it was observed throughout 1995 to 2002 in Brazil, i.e., the decrease of the optimistic bias and the indicators of precision and accuracy do not present satisfactory performance.

The results, besides contributing with the literature on the effects of IFRS in the forecast properties, are also important for the regulatory bodies to make policies that increase the credibility of financial statements and thus stimulate the adherence by market analysts in conducting their forecasts using the informational increment proposed by the standards in the new accounting standard.

The results also alert the target audience of financial information in the new accounting standard, investors, as they may not be benefited by the informational increment of the financial statements in the new accounting standard.

Investors can decide on investments based on reports from market analysts that have not yet captured the benefits proposed by the new accounting standard or that do not consider the informational increment of the financial statements in the new standard in their forecasts and evaluations.

This study shows evidence in Brazil that the IFRS financial statements have not yet provided analysts with the benefits expected for reporting under the new accounting standard, as external information users; on the contrary, analysts' forecast properties performed differently from that expected, generating the discussion about the relevance of IFRS in the production of financial reports, since its use by market analysts did not contribute to increase its performance, in the period studied.

The study, in addition, is limited by the difficulty of obtaining information on market analysts, so much so that it was restricted to the $\mathrm{I} / \mathrm{B} / \mathrm{E} / \mathrm{S}$ database forecasts and the companies followed by analysts. Although the number of companies followed by analysts has increased over time, the research population is still very small.

\section{REFERENCES}

ASHBAUGH, H.; PINCUS, M. Domestic Accounting Standards, International Accounting Standards and the Predictability of Earnings. Journal of Accounting Research, v.39, n.1, p. 417- 434, 2001.

AHMAD-ZALUKI, N. A.; WAN-HUSSIN, W. N. Corporate governance and earnings forecasts accuracy. Asian Review of Accounting, vol. 18, n. 1, p. 50-67, 2010.

BAE, K-H.; TAN, H.; WELKER, M. International GAAP differences: the impact on foreign analysts. The Accounting Review, v. 83, n. 3, p. 593-628, 2008.

BALL, R.; ROBIN, A.; WU. J. S. Incentives versus standards: proprieties if accounting income in four East Asian countries. Journal of Accounting and Economics, v. 36, p. 235-270, 2003.

BARNIV, R.R.; MYRING, M. How would the differences between IFRS and US GAAP affect US analyst performance? Journal of Accounting and Public Policy, v. 34, n.1, nov2014.

BEHN, B. K.; CHOI, J-H.; KANG, T. Audit Quality and Properties of Analyst Earnings Forecasts. The Accounting Review, vol.83, n. 2, p. 327-349, 2008.

BEIRUTH, A. X.; LIMA, G.A.S.F. GALDI, F.C.; ALMEIDA, J.E.F. Comparação da acurácia de analistas com o modelo de OHLSON-JUETTNER (OJ) no mercado brasileiro. Revista de Contabilidade do Mestrado em Ciência Contábeis da UERJ (online), Rio de Janeiro, v.19, n.2, p. 79-98, mai./ago., 2014.

BOFF, L. H; PROCAVIANOY, J.L.; HOPPEN, N. O uso de informações por analistas de investimento na avaliação de empresas: à procura de padrões. Revista de Administração Contemporânea, vol.10, n.4, Curitiba: Out/Dez, 2006. 
BBR

15,3

244

BRASIL. Comissão de Valores Mobiliários. Parecer de orientação no 37, de 22 de setembro de 2011. Available: $<$ http://www.cvm.gov.br/port/infos/Comunicado_Parecer_de_Orientacao_37.asp $>$

BRYAN. D. TIRAS, S.L. The Influence of Forecast Dispersion on the Incremental Explanatory Power of Earnings, Book Value, and Analyst Forecasts on Market Prices. The Accounting Review, v. 82, n.3, p. 651677, May. 2007.

BYARD, D.; LI, Y; YU, Y. The effect of mandatory IFRS adoption on analysts' information environment. Journal of Accounting Research, vol. 49, n. 1, p. 69-96, Mar. 2011.

COELHO, A. C.; LIMA, I. S. Segmentos de governança Bovespa: diferenças nos graus de conservadorismo condicional na divulgação de resultados contábeis. Advances in Scientific and Applied Accounting., vol.1, n.1, p. 17-32, 2008.

COTTER, J; TARCA, A.; WEE, M. IFRS adoption and analysts' earnings forecasts: Australian evidence. Accounting \& Finance, v.52, p. 395-419, 2012.

DALMÁCIO, F. Z.LOPES, A.B; REZENDE, A.J; SARLO NETO, A. Uma análise da relação entre governança corporativa e acurácia das previsões dos analistas do mercado brasileiro. Revista de Administração Mackenzie, v. 14, n.5, p. 104 -139, Sept./Oct. 2013.

DJATEJ, A.; GAO, G.; SARIKAS, R.H.S.; SENTENEY, D.L. An investigation of the impact of degree of IFRS implementation on the comparative accuracy and bias of equity security analysts east and west European firms earnings forecasts. Journal of Applied Business Research, vol 24, n.4, p. 65-81, Dec./2008.

ERNSTERGER, J.; KROTTER, S.; STADLER, C. Analysts Forecast Accuracy in Germany: The Effect of Difference Accounting Principles and Changes of Accounting Principles. Business Research, v. 1, p. 2653, May, 2008.

FÁVERO, L.P; BELFIORE, P.; SILVA, F.L; CHAN, B.L. Análise de dados: modelagem multivariada para tomada de decisões. Rio de Janeiro: Elsevier, 2009.

FRANCO, D. Projeções de lucros sistematicamente exageradas: um estudo para o Brasil. Revista Brasileira de Economia, vol.56, n.4, Rio de Janeiro, Oct./Dec. 2002

GATSIOS, R. C. Acurácia e dispersão das estimativas dos analistas no mercado de capitais brasileiro: Impacto da adoção do padrão IFRS sobre a qualidade preditiva da informação contábil. 2013. 105 p. Dissertação (Mestrado em Ciências Contábeis). Programa de Pós-Graduação em Controladoria e Contabilidade de Ribeirão Preto da Universidade de São Paulo, Ribeirão Preto, 2013.

GRECCO, M. C. P. O. E.. O efeito da convergência brasileira às IFRS no gerenciamento de resultados das empresas abertas brasileiras não financeiras. Brazilian Business Review, v.10, n.4, p. 117-140,2013.

HAUSER, R. Did dividend policy change during the financial crisis? Managerial Finance, vol. 39, 6, p. 584-606, 2013. <http://www.emeraldinsight.com/doi/full/10.1108/03074351311322861>. Accessed on: 14.12.14.

HOUQE, M. N; EASTON, S.; ZIJL, T. Does mandatory IFRS adoption improve information quality in low investor protection countries? Journal of International Accounting, Auditing and Taxation, vol. 23, p. 8797, 2014.

INSTITUTIONAL BROKERS ESTIMATE SYSTEM (I/B/E/S). I/B/E/S on DataStream - User Guide. v. 6. Thomson Reuters: Sept 2013.

JIAO, T.; KONING, M.; MERTENS, G.; ROOSENBOOM, P. Mandatory IFRS adoption and its impact on analysts' forecasts. International Review of Financial Analysis, vol. 21, p. 56-63, Jan.2012.

KIM. S.; KIM, N.; KWON, K-M. Mandatory IFRS Adoption and Financial Analysts' Information Environment: Evidence from Korean Market. Journal of Applied Business Research, vol 32, n.5, Sept. 2016.

LANG, M. H.; LUNDHOM, R.J. Corporate Disclosure Policy and Analyst Behavior. The Accounting and Economics, v. 42, p. 439-458, 1996.

LI, S. Does Mandatory Adoption of International Financial Reporting Standards in the European Union Reduce the Cost of Equity Capital? The Accounting Review, v. 85, p. 607-636, Mar. 2010.

LIMA, V. S.; ILHA, H. F.; SCALZER, R. S.; GALDI, F. C. Análise fundamentalista sob a perspectiva do analista de mercado: um estudo de caso na AES TIETÊ comparando os modelos de fluxo de caixa descontado e AEG Ohlson (1995). In: GONGRESSO USP DE INICIAÇÃO CIENTÍFICA, 6, 2009, São Paulo. Anais... São Paulo: USP, 2009.

LYS, T.; SOO, L. Analysts' forecast precision as a response to competition. Journal of Accounting, Auditing and Finance, v.10, n.4, p. 751-765, 1995.

MACEDO, M. A. S.; ARAUJO, M. B. V.; BRAGA, J. P. Impacto do Processo de Convergência às Normas Internacionais de Contabilidade na Relevância das Informações Contábeis. Revista de Educação e Pesquisa em Contabilidade, v. 6, n.4, p. 367-382, Oct./Dec., 2012 
MARTINEZ, A.L. Como o mercado de capitais brasileiro reage a surpresa nos lucros? REAd, ed. 51, vol.12, n. 3, May/Jun, 2006.

MARTINEZ, A.L. Otimismo e viés de seleção dos analistas. BBR. Brazilian Business Review. Vitória, v. 4, n.2, p.104-118. 2007.

MARTINEZ, A. L; DUMER, M. C. R. Adoption of IFRS and the Properties of Analysts' Forecasts: The Brazilian Case. Revista de Contabilidade e Organizações, vol. 20, p. 3-16, 2014.

MASOUD, N. The effects of mandatory IFRS adoption on financial analysts' forecast: Evidence from Jordan. Cogent Business \& Management, v. 4, Jan. 2017.

MURPHY, T.; O'CONNELL, V.; ÓHOGARTAIGH, C. Discourses surrounding the evolution of the IASB/ FASB Conceptual Framework: What they reveal about the "living law" of accounting. Accounting, Organizations and Society, v. 38, p 72-91, 2013.

NOGUEIRA JUNIOR, E.; JUCÁ, M. N.; MACEDO, M.A.S.; CORRAR, L.J. Início da adoção das IFRAS no Brasil: Os impactos provocados na relação entre lucro r fluxo de caixa operacional. Revista Contabilidade Vista \&Revista, v. 23, n.1, p.47-74, Jan/Mar, 2012.

PALEPU, K. G.; BERNARD, V. L.; HEALY, P. M. Business analysis \& valuation: using financial statements: text and cases. Cincinnati: South-western College Publishing, 2000.

PESSOTTI, T. Impacto da convergência às normas internacionais de contabilidade sobre a acurácia dos analistas do mercado de capitais brasileiro, 2012.70 p. Dissertação (Mestrado em Ciências Contábeis). Fundação Instituto Capixaba de Pesquisas em Contabilidade, Economia e Finanças (FUCAPE), Vitória, 2012.

PETAIBANLUE, J.; WALKER, M.; LEE, E. When did analyst forecast accuracy benefit from increased crossborder comparability following IFRS adoption in the EU?. International Review of Financial Analysis, vol. 42, p. 278-291, Dec. 2015. Doi: 10.1016/j.irfa.2015.08.004.

RAVENSCROFT, S.; WILLIAMS, P. Making imaginary worlds real: The case of expensing employee stock options. Accounting Organizations and Society, v. 34, p. 770-786, 2009.

RICHARDSON, S. A; TEOH, S. S. H; WYSOCHI, P. D. Tracking analysts' forecasts over the annual earnings horizon: are analysts' forecasts optimistic or pessimistic? Working Paper. University of Michigan, 1999.

SAITO, R.; VILLALOBOS, S. J. S.; BENETTI, C. Qualidade das projeções dos analistas sell-side: evidência empírica no mercado brasileiro. Revista de Administração - RAUSP, São Paulo, v. 43, n. 4, p. 356-369, 2008.

TAN, H.; WANG, S.; WELKER, M. Analyst Following and Forecast Accuracy After mandated IFRS Adoptions. Journal of Accounting Research, vol, 49, p. 1307 -1357, Dec., 2011.

There is no conflict of interests in this study. The article was done collaboratively at all stages of its elaboration. 